\title{
Phytosynthesis of Silver Nanoparticles Using Myrtus communis L. Leaf Extract and Investigation of Bactericidal Activity
}

\author{
M.R. AJDARI ${ }^{1,2}$ G.H. TONDRO,${ }^{1}$ N. SATTARAHMADY,${ }^{1,3,4,5}$ A. PARSA, ${ }^{1}$ \\ and $\mathrm{H}$. HELI ${ }^{1,6,7}$ \\ 1.-Nanomedicine and Nanobiology Research Center, Shiraz University of Medical Sciences, \\ Shiraz, Iran. 2.-Student Research Committee, School of Medicine, Shiraz University of Medical \\ Sciences, Shiraz, Iran. 3.-Department of Medical Physics, School of Medicine, Shiraz \\ University of Medical Sciences, Shiraz, Iran. 4.-e-mail: sattarahmady@yahoo.com. 5.-e-mail: \\ nsattar@sums.ac.ir.6.—e-mail: hheli7@yahoo.com. 7.—e-mail: heli@sums.ac.ir
}

Silver nanoparticles have been synthesized using only Myrtus communis L. leaf extract by a facile procedure without other reagents. The extract played the roles of both reducing and capping agent. The nanoparticles were characterized using field-emission scanning microscopy, and remained stable for at least 3 weeks. Antibacterial activity of the nanoparticles was evaluated toward Escherichia coli, Bacillus subtilis, Pseudomonas aeruginosa, Staphylococcus aureus, methicillin-resistant Staphylococcus aureus, and Enterococcus faecalis based on inhibition zone disk diffusion assays. The minimum inhibitory and bactericidal concentrations of the nanoparticles were obtained. Mechanisms for the antibacterial activity were proposed.

Key words: Ag, green synthesis, antibacterial, disk diffusion

\section{INTRODUCTION}

In recent years, synthesis of noble-metal nanostructures of gold, palladium, platinum, and silver has attracted great attention due to their applications in catalysis, ${ }^{1}$ diagnosis,${ }^{2}$ theranostics, ${ }^{3}$ optical and visual detection, ${ }^{4,5}$ therapy ${ }^{6}$ plasmonics,${ }^{7}$ imaging, ${ }^{8}$ electrocatalysis and electroanalysis ${ }^{9-11}$ and sensing, biosensing, and aptasensing. ${ }^{12-15}$ In this regard, a lot of attention has been paid to synthesis of nanostructured materials using natural species such as algae, yeasts, bacteria, fungi, biological compounds, and plant extracts. ${ }^{16}$ In such synthesis of metal nanostructures, these compounds act simultaneously as reducing, shape-directing, structure-stabilizing, capping, and aggregation-inhibiting agents due to the proteins, enzymes, carbohydrates, aldehydes, etc. that they contain. Natural compounds also present limited or no toxicity, danger, and environmental problems, and are relatively low cost. Use of plant and herbal

(Received June 21, 2017; accepted September 1, 2017; published online September 13, 2017) extracts therefore provides an ecofriendly route for controlled and precise synthesis of metal nanostructures of various sizes and shapes. ${ }^{17,18}$ To date, several methods have been reported for phytosynthesis of silver nanostructures including nanoparticles, ${ }^{18}$ nanoflowers, ${ }^{19}$ nanorods, ${ }^{20}$ and nanoflakes. ${ }^{21}$

Presence of microorganisms in textile fabrics, medical implants and tools, food containers, and water transport and treatment systems can cause infectious diseases and must be controlled; For example, Bacillus subtilis and Pseudomonas aeruginosa cause brain inflammatory diseases, allergic sensitivity, ${ }^{22,23}$ and lung infections or pneumonia in patients with compromised immune systems and hospital infections, respectively. ${ }^{24,25}$ On the other hand, considering the increased resistance of microbial organisms toward current biocides, as well as healthcare costs, ${ }^{26}$ much research has been conducted to develop new and improved antimicrobial agents. ${ }^{27}$ Using nanotechnology, it is possible to develop novel inorganic nanomaterials with bactericidal activity as alternative replacements for treatment of bacterial diseases. These small-sized nanomaterials exhibit high surface-to-volume ratio, and can affect biological entities through different 
routes, such as attachment to the membranes and walls of microorganism, generation of reactive oxygen species (ROS), binding to proteins, alteration of electron transfer pathways, generation of high ion concentrations and gradients, and changing their DNA conformation, leading to cell death. ${ }^{2-24,28}$

Silver nanostructures, mainly nanoparticles, have applications in industry and medicine due to the intrinsic properties of silver and the special properties arising from their nanosized dimensions, such as high electrical conductivity, stability, and photonic, catalytic and antibacterial activities. ${ }^{25,28,29}$ Due to the toxicity of silver to microorganisms, it and materials containing it are used in coatings, fillers, filters, textiles, clothes, and medical tools and devices. ${ }^{28,30,31}$ Silver-containing nanomaterials can attach to cell walls, enter cells, ${ }^{32}$ attach to membrane proteins and respiratory chains in mitochondria, and generate $\operatorname{ROS}^{33}$ by catalyzing partial reduction reaction of oxygen. ${ }^{34}$ These nanomaterials can also release silver ions, followed by protein binding (via thiol groups of protein) and inactivation, DNA binding (via phosphate groups of DNA), and alteration of the DNA structure. ${ }^{35,36}$

Myrtus communis L. from the Myrtaceae family, generally known as myrtle, is an evergreen shrub and aromatic herb with rough bark and hastate, linear, and thick leaves, being used extensively worldwide. ${ }^{37}$ It has traditional culinary and medicine uses. ${ }^{37-39}$ Recently, it was shown that the myrtle plant contains many antioxidant components that can be used as reductant agents in biosynthesis of metal nanoparticles. ${ }^{39}$

Silver nanoparticles were synthesized in the present study using $M$. communis L. leaf extract, then tested against various Gram-positive and Gram-negative strains. The mechanism of antibacterial activity of the nanoparticles was also investigated.

\section{EXPERIMENTAL PROCEDURES}

All chemicals and culture media were purchased from Schalau (Spain). M. communis L. leaves were prepared from areas near Shiraz, Iran. Gramnegative bacteria Escherichia coli (EC, PTCC 1399) and Pseudomonas aeruginosa (PA, PTCC 1430), and Gram-positive bacteria Bacillus subtilis (BS, PTCC 1023), Enterococcus faecalis (EF, PTCC 1237), Staphylococcus aureus (SA, PTCC 1431), and methicillin-resistant Staphylococcus aureus (MRSA, PTCC 1764) were received from Pasteur Institute (Iran).

To prepare $M$. communis L. leaf extract, leaves were collected and washed several times thoroughly using distilled water then dried at room temperature for several weeks. The leaves were then ground and bunted to obtain uniform powder. Leaf extract was prepared by addition of $322 \mathrm{mg}$ ground powder to $100 \mathrm{~mL}$ hot distilled water at $80^{\circ} \mathrm{C}$ for $15 \mathrm{~min}$. The extract was then filtered using filter paper to obtain clear solution with very light-green color without any suspended solid. The concentration of the extract was $3.22 \mathrm{~g} \mathrm{~L}^{-1}$ on initial dried leaf basis.

To synthesize silver nanoparticles, $10 \mathrm{~mL}$ extract was mixed with $1.0 \mathrm{~mL} 20 \mathrm{mmol} \mathrm{L}^{-1}$ silver nitrate solution with gentle shaking at room temperature in the dark. The mixture was kept for $20 \mathrm{~min}$ to complete the reaction (with yield of $\sim 98 \%$ ). During that time, the color of the solution changed from very light green to light brown, indicating completion of the synthesis process. The nanoparticles were separated by centrifugation at $15,000 \mathrm{rpm}$, washed several times using distilled water, then subjected to further studies. Fresh phytosynthesized silver nanoparticles were employed in all experiments.

The content of the extract and formation of silver nanoparticles were monitored by ultraviolet-visible (UV-Vis) spectra recorded using a Rayleigh 2100 spectrophotometer (China).

The zeta potential of the silver nanoparticles was measured using a Malvern Nano-ZS ZEN 3600 (England).

Field-emission scanning electron microscopy (FESEM) and scanning electron microscopy (SEM) were performed using a MIRA3 TESCAN-XMU (Czech Republic) microscope, and VEGA TESCANXMU (Czech Republic) microscope, respectively. For preparation of silver samples, a droplet of nanoparticle suspension was dropped on a microscope slide, then coated with a 2 -nm- to 5 -nm-thick gold film by sputtering. For bacterial sample preparation, untreated cells and cells treated with the $50 \%$ lethal dose $\left(\mathrm{LD}_{50}\right)$ of silver nanoparticles were collected by centrifugation at $1000 \mathrm{rpm}$ for $5 \mathrm{~min}$, then washed three times with $0.1 \mathrm{~mol} \mathrm{~L}^{-1}$ phosphate buffer $(\mathrm{pH}$ 7.4). The cells were then transferred to $0.1 \mathrm{~mol} \mathrm{~L}^{-1}$ phosphate buffer ( $\mathrm{pH} 7.4$ ) containing $2 \%$ glutaraldehyde at $2^{\circ} \mathrm{C}$ to $4^{\circ} \mathrm{C}$ for $12 \mathrm{~h}$. They were then precipitated by centrifugation, and washed three times with $0.1 \mathrm{~mol} \mathrm{~L}^{-1}$ phosphate buffer ( $\mathrm{pH}$ 7.4). Then, the samples were poststabilized for $30 \mathrm{~min}$ in $1 \%$ aqueous solution of osmium tetroxide solution at room temperature. The samples were precipitated again and washed twice with deionized water. Dehydration of the samples was done for $3 \mathrm{~min}$ in an acetone gradient of $35 \%, 50 \%, 70 \%, 80 \%, 95 \%$, and $100 \%$, respectively. The final suspension of the sample in $100 \%$ acetone was dropped onto a microscope slide and coated with a 2-nm- to 5-nm-thick gold film by sputtering.

The antibacterial activity of the silver nanoparticles was investigated by disc diffusion method on bacteria seeded on agar plates using spread plating technique. Sterilized paper discs were imbued with nanoparticle suspension, dried at ambient temperature, introduced into the dishes, and incubated at $37^{\circ} \mathrm{C}$ for $18 \mathrm{~h}$ to $24 \mathrm{~h}$. The inhibition zones were measured based on four replicates. Blank paper discs and imbued disks with extract were employed as negative and positive control, respectively. 


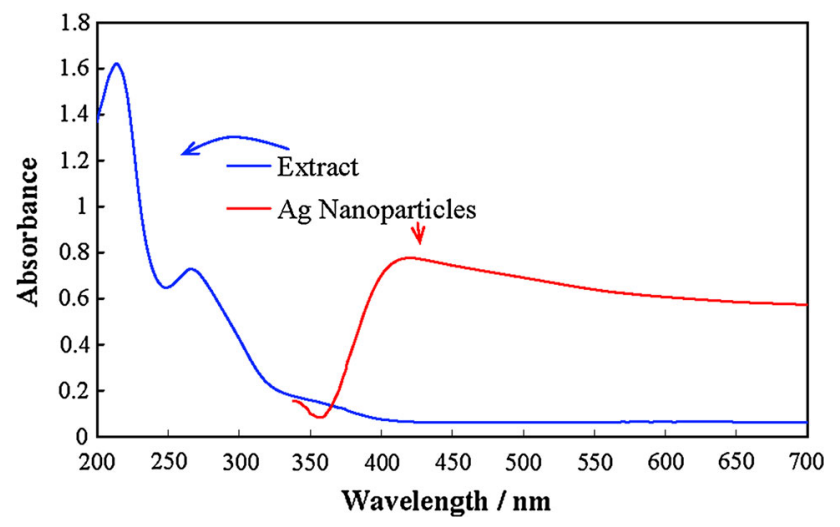

Fig. 1. UV-Vis spectra for solutions of $0.81 \mathrm{~g} \mathrm{~L}^{-1}$ of Myrtus communis $\mathrm{L}$. leaf extract and $0.45 \mathrm{mmol} \mathrm{L}^{-1}$ of silver nanoparticles.

The minimum inhibitory concentration (MIC) and minimum bactericidal concentration (MBC) were measured on enzyme-linked immunosorbent assay (ELISA) plates containing $180 \mu \mathrm{L}$ nutrient broth and $20 \mu \mathrm{L}$ freshly prepared bacterial suspension with final concentration of $10^{5}$ colony-forming units (CFU) $\mathrm{mL}^{-1}$. The plates were kept at $37^{\circ} \mathrm{C}$, then the contents of the wells was recultured in Petri dishes using the pour plate technique to confirm inhibition of bacterial growth.

\section{RESULTS AND DISCUSSION}

Figure 1 shows the UV-Vis spectra of solutions of $0.81 \mathrm{~g} \mathrm{~L}^{-1}$ of extract and $0.45 \mathrm{mmol} \mathrm{L}{ }^{-1}$ of silver nanoparticles. The spectrum of the extract confirmed the presence of various compounds in the UV absorption region with minor absorption in the visible region. On the other hand, silver nanoparticles presented maximum absorption at $414 \mathrm{~nm}$. This absorption is due to the surface plasmon resonance (SPR) of the nanoparticles. From the main components reported to be included in $M$. communis L. extract/oil, ${ }^{40-42}$ nerol and geraniol as alcohols have the potential to reduce silver ions (forming the corresponding aldehyde). From the wavelength of the absorption maximum $\left(\lambda_{\max }\right)$, the size of the nanoparticles can be estimated ${ }^{43,44}$ by nonlinear regression on a plot of SPR wavelength versus size (Fig. S1, Electronic Supplementary Material). Based on this analysis, a size of $41 \mathrm{~nm}$ was obtained for the nanoparticles.

Figure 2 presents FESEM images of silver nanoparticles recorded at different magnifications, showing individual particles with regular triangular to hexagonal shape. Mean particle size of $84 \pm 45 \mathrm{~nm}(n=50)$ was obtained for the sample. Higher-magnification images indicated that these particles themselves comprised very smaller adhered nanoparticles. Comparison of these results with those in Fig. 1 and the maximum of the size distribution indicates that the nanoparticles observed in FESEM images were agglomerated,
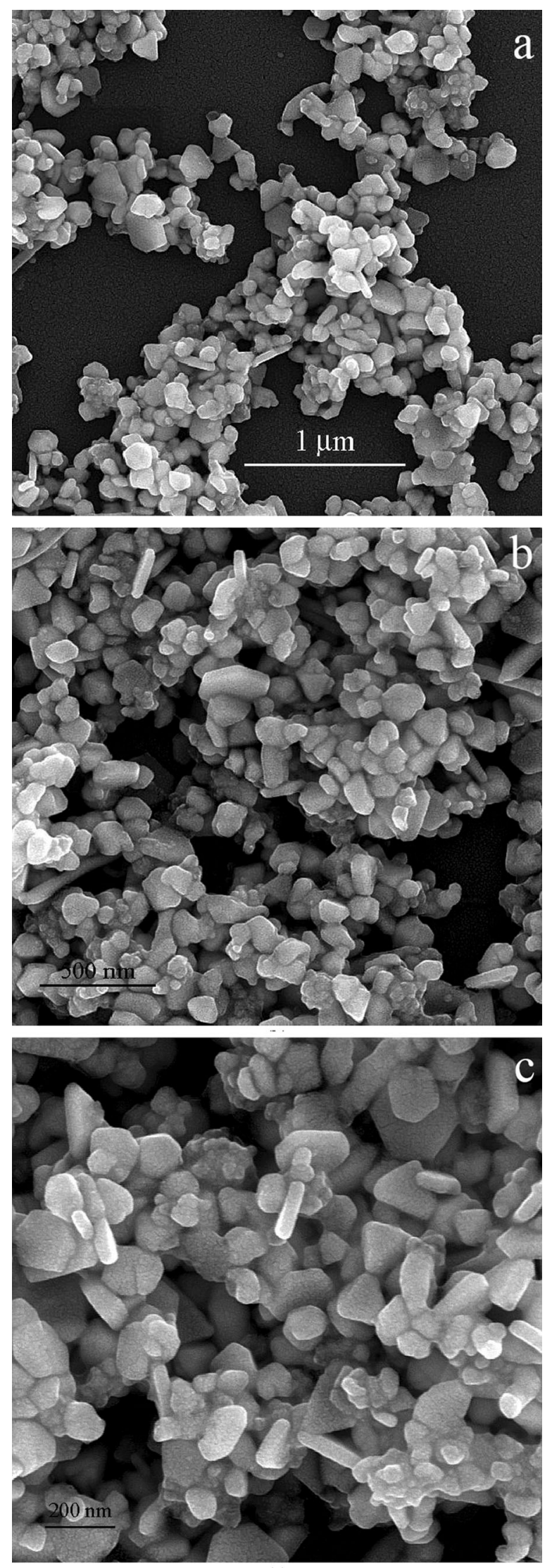

Fig. 2. FESEM images of silver nanoparticles at low (a), middle (b), and high (c) magnifications. 
resulting from the method used to prepare FESEM samples.

The antibacterial activity of the synthesized silver nanoparticles toward six types of bacterial species was investigated by disk diffusion method. The negative control showed no zone of inhibition for all

Table I. Inhibition zone (IZ) of Myrtus communis $\mathrm{L}$. leaf extract against various microorganisms

\begin{tabular}{lc}
\hline Strain & IZ (mm) \\
\cline { 1 - 1 } Escherichia coli & - \\
Bacillus subtilis & - \\
Pseudomonas aeruginosa & - \\
Staphylococcus aureus & 13 \\
Methicillin-resistant Staphylococcus aureus & 11 \\
Enterococcus faecalis & - \\
\hline
\end{tabular}

Table II. MIC and MBC of Myrtus communis L. leaf extract against various microorganisms

\begin{tabular}{lccc}
\hline Strain & MIC $\left(\mathbf{g ~ L}^{-\mathbf{1}}\right)$ & & $\mathbf{M B C}\left(\mathbf{g ~ L}^{-\mathbf{1}}\right)$ \\
\cline { 1 - 1 } Escherichia coli & - & - \\
Bacillus subtilis & & - & - \\
Pseudomonas aeruginosa & & - & - \\
Staphylococcus aureus & & 0.81 & - \\
Methicillin-resistant & 1.61 & - \\
Staphylococcus aureus & - & - \\
Enterococcus faecalis & - & \\
\hline
\end{tabular}

of the strains, while the positive control showed only a weak antibacterial effect on SA and MRSA. The inhibition zone (IZ), MIC, and MBC results for the positive control are presented in Tables I and II. On the other hand, the nanoparticles exhibited strong bactericidal effect; the IZ, MIC, $\mathrm{MBC}$, and $\mathrm{LD}_{50}$ values are presented in Tables III and IV. Based on the results, the silver nanoparticles exhibited bactericidal effect on both the Gram-positive and Gram-negative strains, with the highest antibacterial activity toward $\mathrm{BS}$ and SA, and the lowest towards PA. Based on these results, the silver nanoparticles synthesized using $M$. communis $\mathrm{L}$. leaf extract showed better or comparable antibacterial activity compared with other inorganic antibiotics. ${ }^{45-49}$

Silver-containing nanomaterials can present antibacterial activity via several routes: (1) by attaching to the walls of the cell and entering inside the cells, ${ }^{32}(2)$ by attaching to membrane proteins and respiratory chains of mitochondria, (3) by generating $\operatorname{ROS}^{33}$ by catalyzing partial reduction reaction of oxygen, ${ }^{34}$ (4) by releasing silver ions followed by protein binding (via thiol groups of protein) and inactivation and DNA binding (via phosphate groups of DNA), and (5) by altering bacterial structure, physiology, and metabolism. ${ }^{35,36}$ To investigate the probable mechanism of the antibacterial activity of the nanoparticles, various experiments were carried out. Firstly, bacterial culturing was performed in presence of $10 \mathrm{mmol} \mathrm{L}{ }^{-1}$ of either $N$-acetyl L-cysteine or ascorbic acid. In presence of these antioxidants, only EC

Table III. IZ of silver nanoparticles against various microorganisms

\begin{tabular}{|c|c|c|c|c|c|}
\hline Strain & 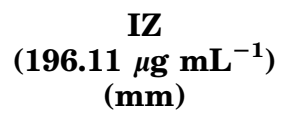 & $\begin{array}{c}\text { IZ } \\
\left(\mathbf{9 8 . 0 5 ~} \mu \mathrm{g} \mathrm{mL} \mathbf{~}^{-1}\right)\end{array}$ & $\begin{array}{c}\text { IZ } \\
\left(\begin{array}{c}\text { (mm) } \\
\mu \mathrm{gmL}\end{array}\right.\end{array}$ & $\underset{(\mathbf{m m})}{\text { IZ }}$ & $\begin{array}{c}\mathrm{IZ} \\
\underset{(\mathbf{m m})}{\left.\mu \mathrm{g} \mathrm{mL}^{-1}\right)}\end{array}$ \\
\hline Escherichia coli & 13 & 10 & - & - & - \\
\hline Bacillus subtilis & 15 & 13 & 10 & 8 & - \\
\hline Pseudomonas aeruginosa & 11 & 8 & - & - & - \\
\hline Staphylococcus aureus & 14 & 12 & 9.5 & - & - \\
\hline Methicillin-resistant & 12 & 9.5 & 8 & - & - \\
\hline Staphylococcus aureus & & & & & \\
\hline Enterococcus faecalis & 9.5 & 8.6 & - & - & - \\
\hline
\end{tabular}

Table IV. MIC, MBC, and $\mathrm{LD}_{50}$ of silver nanoparticles against various microorganisms

\begin{tabular}{|c|c|c|c|}
\hline Strain & $\operatorname{MIC}\left(\mu \mathrm{g} \mathrm{mL} L^{-1}\right)$ & $\operatorname{MBC}\left(\mu \mathrm{g} \mathrm{mL} L^{-1}\right)$ & $\operatorname{LD50}\left(\mu \mathrm{g} \mathrm{mL}^{-1}\right)$ \\
\hline Escherichia coli & 24.51 & 49.02 & 16.34 \\
\hline Bacillus subtilis & 12.26 & 24.51 & 9.81 \\
\hline Pseudomonas aeruginosa & 32.68 & 65.39 & 16.34 \\
\hline Staphylococcus aureus & 12.26 & 16.34 & 8.17 \\
\hline Methicillin-resistant Staphylococcus aureus & 16.34 & 49.02 & 12.26 \\
\hline Enterococcus faecalis & 24.51 & 65.39 & 12.26 \\
\hline
\end{tabular}



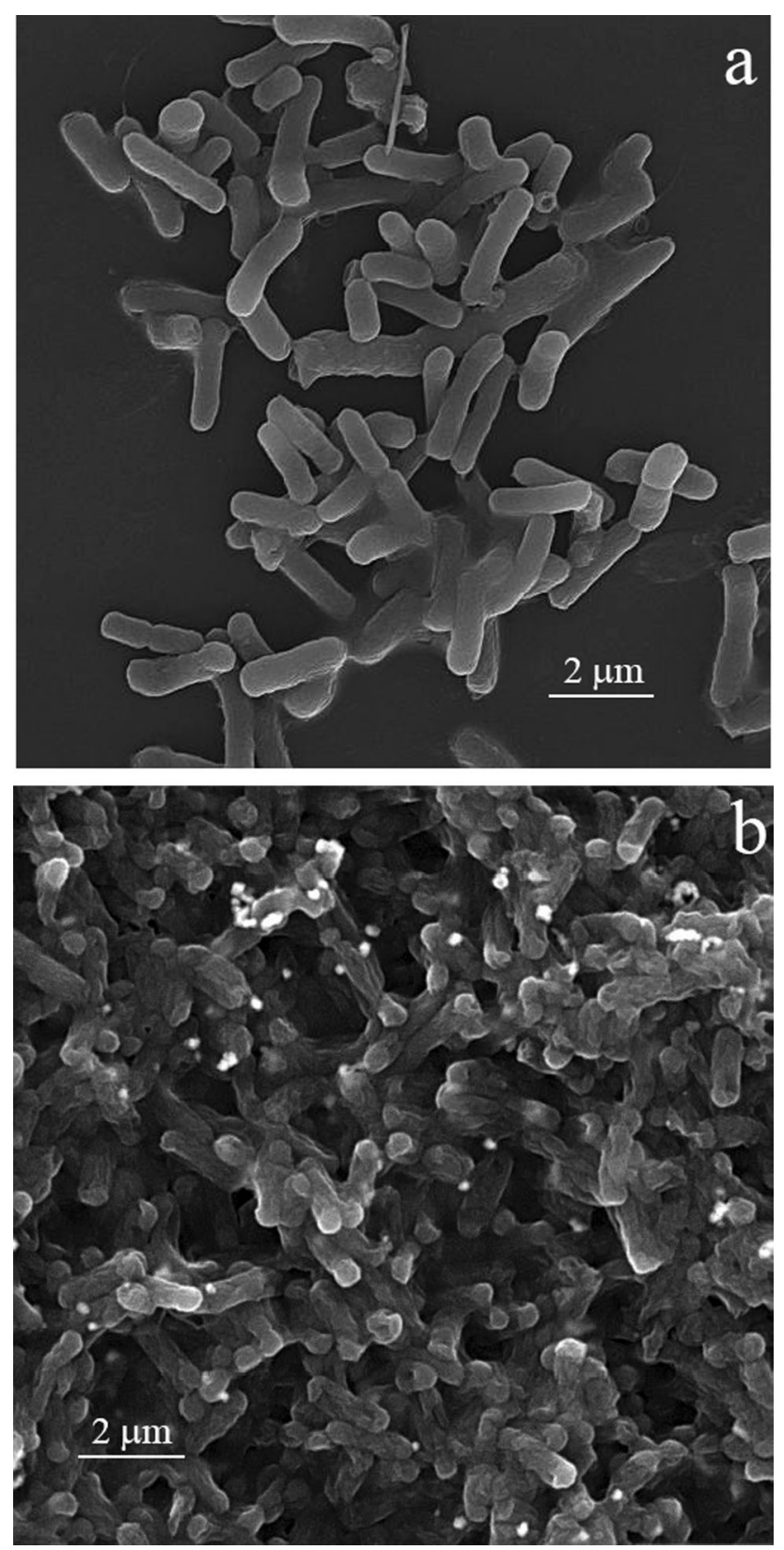

Fig. 3. SEM images from EC strain before (a) and after (b) treatment with silver nanoparticles.

grew, showing the same MIC and 600-nm absorbance values (compared with absence of antioxidant), while no growth was observed for the other strains. This indicates that ROS was the dominant mechanism for the bactericidal effect of the silver nanoparticles toward EC, while other mechanism(s) have to be provided for the other strains rather than ROS generation. The zeta potential for the nanoparticles was measured to be $-16.2 \pm 6.5 \mathrm{mV}$. On the other hand, cell surface charge is usually negative. Therefore, attachment of the silver nanoparticles to bacteria cell walls was not the main mechanism for the antibacterial activity. SEM images were recorded from all the tested strains before and after treatment with silver nanoparticles. In the images recorded for EC (Fig. 3), shrinkage and crumpling of bacteria were observed. However, there were no significant changes in the structure and cell wall morphology of the other bacteria (Fig. S2). This further confirms that no (strong) interactions occurred between the nanoparticles and these strains. The changes in the morphology of EC after treatment with the nanoparticles could also be related to the effect of ROS generation on this strain. To detect release of silver ions, the medium of the bacteria culture was treated with nanoparticles. It was found that, after $24 \mathrm{~h}$, silver ions were released into the medium, as confirmed by precipitation using chloride. Therefore, silver ion release (accompanied by ROS generation for EC) was the main mechanism of the antibacterial activity of the nanoparticles. Small silver nanoparticles have high surface energy and instability, and tend to dissolve in the medium at a high rate.

\section{CONCLUSIONS}

A simple and green route is proposed for synthesis of silver nanoparticles using $M$. communis L. leaf extract without any other chemicals. The extract contained reducible compounds which could reduce silver ions, with the potential to reduce other noblemetal ions such as gold, palladium, and probably platinum. The bactericidal action of the synthesized nanoparticles was evaluated against various Grampositive and Gram-negative strains. The main mechanism of antimicrobial activity was silver ion release into the culture medium.

\section{ACKNOWLEDGEMENTS}

The study was supported by the Research Council of Shiraz University of Medical Sciences (13685).

\section{ELECTRONIC SUPPLEMENTARY MATERIAL}

The online version of this article (doi: 10.1007/s11664-017-5784-2) contains supplementary material, which is available to authorized users.

\section{REFERENCES}

1. L. He, F. Weniger, H. Neumann, and M. Beller, Angew. Chem. Int. Ed. 55, 12582 (2016).

2. R.C. Popescu, M.O.M. Fufa, and A.M. Grumezescu, Rom. J. Morphol. Embryol. 56, 635 (2015).

3. Y. Yu, B.Y.L. Mok, X.J. Loh, and Y.N. Tan, Adv. Healthc. Mater. 5, 1844 (2016).

4. N. Sattarahmady, A. Movahedpour, H. Heli, and G.R. Hatam, Sens. Actuators B 235, 723 (2016).

5. N. Sattarahmady, G.H. Tondro, M. Gholchin, and H. Heli, Biochem. Eng. J. 97, 1 (2015).

6. S. Kishorea and P. Radhika, Res. J. Biotechnol. 11, 136 (2016). 
7. S. Gwo, H.-Y. Chen, M.-H. Lin, L. Sun, and X. Li, Chem. Soc. Rev. 45, 5672 (2016).

8. J.A. Coulter, K.T. Butterworth, and S. Jain, Br. J. Radiol. 88, 1 (2015).

9. A. Rahi, K. Karimian, and H. Heli, Anal. Biochem. 497, 39 (2016).

10. H. Heli and A. Rahi, Recent Pat. Nanotechnol. 10, 86 (2016).

11. A. Rahi, N. Sattarahmady, R.D. Vais, and H. Heli, Sens. Actuators B 210, 96 (2015).

12. H. Heli and O. Amirizadeh, Mater. Sci. Eng. C 63, 150 (2016).

13. A. Rahi, N. Sattarahmady, and H. Heli, Sci. Rep. 5, 1 (2015).

14. A. Rahi, N. Sattarahmady, and H. Heli, Talanta 156, 218 (2016).

15. M. Moradi, N. Sattarahmady, A. Rahi, G.R. Hatam, S.M.R. Sorkhabadi, and H. Heli, Talanta 161, 48 (2016).

16. N. Kulkarni and U. Muddapur, J. Nanotechnol. 2014, 1 (2014).

17. A.K. Mittal, Y. Chisti, and U.C. Banerjee, Biotechnol. Adv. 31, 346 (2013).

18. N. Roy, A. Gaur, A. Jain, S. Bhattacharya, and V. Rani, Environ. Toxicol. Pharmacol. 36, 807 (2013).

19. X. Jing, J. Huang, L. Wu, D. Sun, and Q. Li, J. Nanopart. Res. 16, 1-10 (2014).

20. S.J.P. Jacob, H. Mohammed, K. Murali, and M. Kamarudeen, Colloids Surf. B 98, 7 (2012).

21. S. Kaviya, J. Santhanalakshmi, and B. Viswanathan, $M a-$ ter. Lett. 67, 64 (2012).

22. C. Ewald, S. Kuhn, and R. Kalff, Neurosurg. Rev. 29, 163 (2006).

23. L. Liu, K. Xu, H. Wang, P.K.J. Tan, W. Fan, S.S. Venkatraman, L. Li, and Y.-Y. Yang, Nat. Nanotechnol. 4, 457 (2009).

24. V. Balloy, A. Verma, S. Kuravi, M. Si-Tahar, M. Chignard, and R. Ramphal, J. Infect. Dis. 196, 289 (2007).

25. J. Rello, P. Jubert, J. Valles, A. Artigas, M. Rue, and M.S. Niederman, Clin. Infect. Dis. 23, 973 (1996).

26. P.W. Stone, Expert Rev. Pharmacoecon. Outcomes Res. 9, 417 (2009).

27. M.A. Fischbach and C.T. Walsh, Science 325, 1089 (2009).

28. L. Rizzello and P.P. Pompa, Chem. Soc. Rev. 43, 1501 (2014).
29. M. Ovais, A.T. Khalil, A. Raza, M.A. Khan, I. Ahmad, N.U. Islam, M. Saravanan, M.F. Ubaid, M. Ali, and Z.K. Shinwari, Nanomedicine 12, 3157 (2016).

30. M. Polivkova, T. Hubacek, M. Staszek, V. Svorcik, and J. Siegel, Int. J. Mol. Sci. 18, 419 (2017).

31. S. Eckhardt, P.S. Brunetto, J. Gagnon, M. Priebe, B. Giese, and K.M. Fromm, Chem. Rev. 113, 4708 (2013).

32. Q.L. Feng, J. Wu, G.Q. Chen, F.Z. Cui, T.N. Kim, and J.O. Kim, J. Biomed. Mater. Res. 52, 662 (2000).

33. E.T. Hwang, J.H. Lee, Y.J. Chae, Y.S. Kim, B.C. Kim, B.I. Sang, and M.B. Gu, Small 4, 746 (2008).

34. S.J. Stohs and D. Bagchi, Free Radic. Biol. Med. 18, 321 (1995).

35. C.-N. Lok, C.-M. Ho, R. Chen, Q.-Y. He, W.-Y. Yu, H. Sun, P.K.-H. Tam, J.-F. Chiu, and C.-M. Che, J. Proteome Res. 5, 916 (2006).

36. Y. Matsumura, K. Yoshikata, S.-I. Kunisaki, and T. Tsuchido, Appl. Environ. Microbiol. 69, 4278 (2003).

37. V. Aleksic and P. Knezevic, Microbiol. Res. 169, 240 (2014).

38. M. Mahboubi, J. Ethnopharmacol. 193, 481 (2016).

39. G. Alipour, S. Dashti, and H. Hosseinzadeh, Phytother. Res. 28, 1125 (2014).

40. C.N. Hassiotis and D.M. Lazari, Int. Biodeterior. Biodegrad. 64, 356 (2010).

41. W.A. Wannes, B. Mhamdi, and B. Marzouk, Food Chem. 112, 621 (2009)

42. D. Yadegarnia, L. Gachkar, M.B. Rezaei, M. Taghizadeh, S.A. Astaneh, and I. Rasooli, Phytochemistry 67, 1249 (2006).

43. http://www.cytodiagnostics.com/store/pc/Silver-Nanopartic le-Properties-d11.htm. Accessed 11 Sept 2017.

44. https://nanocomposix.com/pages/silver-nanoparticles-physi cal-properties. Accessed 11 Sept 2017.

45. M. Khatami, R. Mehnipor, M.H.S. Poor, and G.S. Jouzani, J. Clust. Sci. 27, 1601 (2016).

46. M. Khatami, E. Amini, A. Amini, S.M. Mortazavi, Z.K. Farahani, and H. Heli, Iran. J. Biotechnol. 15, 95 (2017).

47. M. Khatami, M.S. Nejad, S. Salari, and P.G.N. Almani, IET Nanobiotechnol. 10, 237 (2016).

48. E. Zare, S. Pourseyedi, M. Khatami, and E. Darezereshki, J. Mol. Struct. 1146, 96 (2017).

49. M. Khatami, H. Heli, P.M. Jahani, H. Azizi, and M.A.L. Nobre, IET Nanobiotechnol. 11, 709 (2017). 